\title{
REFORMA ADMINISTRATIVA E DIREITO ADQUIRIDO
}

\section{PAULO MODESTO*}

\begin{abstract}
1. Do conceito de direito adquirido em vigor no Brasil. 2. Como funciona na prática a garantia que protege o direito adquirido? 3. Direitos adquiridos e reforma constitucional: a questão das cláusulas pétreas. 4. Direito adquirido e alteração abstrata do regime jurídico dos servidores públicos. 5. Sentido lógico e jurídico das emendas sobre direito adquirido na Reforma Administrativa.
\end{abstract}

\section{Do conceito de direito adquirido em vigor no Brasil}

A Constituição Federal enuncia no art. 59, inciso XXXVI: “a lei não prejudicará o direito adquirido, o ato jurídico perfeito e a coisa julgada". Mas não define a extensão e o conteúdo desses conceitos jurídicos.

A Lei de Introdução ao Código Civil (Decreto-lei 4.657/42, com as alterações produzidas pela Lei n. 3.238/57), entretanto, dispõe:

“Art. 60. A lei em vigor terá efeito imediato e geral, respeitados o ato jurídico perfeito, o direito adquirido e a coisa julgada.

§ 22. Consideram-se adquiridos assim os direitos que o seu titular, ou alguém por ele, possa exercer, como aqueles cujo começo de exercício tenha termo prefixo, ou condição preestabelecida inalterável, a arbítrio de outrem."

Diante dessa definição legal duas orientações tiveram curso.

Segundo a primeira, não tendo a Constituição definido o conceito de direito adquirido, caberia à lei ordinária preencher o conceito, estabelecendo os seus limites, considerando desde logo de forma necessária apenas a garantia do ato jurídico perfeito e da coisa julgada (v.g., na doutrina, R. LIMONGI FRANÇA, $A$ Irretroa-

* Assessor Especial do Ministro da Administração Federal e Reforma do Estado do Brasil. Professor de Direito da Universidade Federal da Bahia. Membro do Instituto Brasileiro de Direito Administrativo, do Ministério Público e do Instituto de Advogados do Estado da Bahia.

R. Dir. Adm.,

Rio de Janeiro, 211: 79-94,

jan./mar. 1998 
tividade das Leis e o Direito Adquirido, 4a ed., São Paulo, Ed. RT, 1994, p. 210-1; nos tribunais, no STF, consta apenas o AI n. 135.632, Rel. Min. CELSO DE MELLO, BDA, dez./1995, p. 773, com a seguinte ementa: "Embora a Constituição mencione a garantia do direito adquirido, o conceito da expressão é regulado pela Lei de Introdução. Não cabe, assim, recurso extraordinário, posto que a alegada violação operaria por via reflexa").

Para a segunda orientação, porém, a definição legal de direito adquirido não vincula a jurisdição constitucional nem aprisiona a interpretação da norma constitucional que tutela os direitos adquiridos aos limites enunciados na Lei de Introdução ao Código Civil. Entende-se que, embora possa influenciar a interpretação da matéria, a definição legal não pode dispor do núcleo essencial da norma constitucional de proteção aos direitos adquiridos nem subtrair do plano constitucional o problema do alcance e do conteúdo da norma de garantia.

Esta última é a orientação adotada neste trabalho. A Constituição não se interpreta mediante a lei ordinária; a lei é que tem a sua interpretação condicionada pela Constituição. A garantia constitucional inscrita no art. 5, XXXVI, por expressa determinação constitucional, tem aplicação imediata ( $a r t .5^{\circ}, \S 1^{2}, C F$ ), independendo de preceito legal regulador. Se o conceito de direito adquirido constituísse matéria de caráter ordinário, a garantia constitucional do direito adquirido estaria de modo indireto à disposição do legislador, subordinada aos seus humores, esvaziada enquanto norma de proteção individual. Além disso, teríamos de admitir o paradoxo de um limite ao legislador depender da atuação do próprio legislador.

$\mathrm{Na}$ doutrina nacional, diversos autores adotam perspectiva semelhante. PONTES DE MIRANDA, por exemplo, considera as definições da Lei de Introdução ao Código Civil sobre direito adquirido, ato jurídico perfeito e coisa julgada sem qualquer "significação no plano do direito constitucional" e, de outra parte, "tautológicas". O conceito de direito adquirido é tratado pelo autor como um conceito "científico" que foi "constitucionalizado" (Comentários à Constituição de 1967, com a Emenda n. 1, de 1969. $3^{2}$ ed., Rio de Janeiro, Forense, 1967, pp. 64, 65 e 72). OVÍDIO BERNARDI, por sua vez, enfatiza que "se um legislador elabora uma lei, deve respeitar o direito adquirido. Mas se fica a seu cargo dizer o que é direito adquirido, então nada vale a exigência constitucional." “"O Direito Adquirido e o seu Problema Conceitual", RT, vol. 284, 1959, p. 24-7).

Neste contexto, adotada a segunda orientação, parece evidente o papel insubstituível que ocupa a construção pretoriana e permanente dos tribunais, em especial do SUPREMO TRIBUNAL FEDERAL, com o auxílio da doutrina jurídica, na tarefa de concretizar a cada passo o conteúdo e a extensão da norma de proteção ao direito adquirido em vigor no Brasil, uma vez que esta garantia entre nós possui matriz constitucional. É a jurisprudência dos tribunais superiores o veículo por excelência de tradução do direito vigente entre nós para a matéria.

\section{Como funciona na prática a garantia que protege o direito adquirido?}

A função específica da garantia do direito adquirido é assegurar, no tempo, a manutenção dos efeitos jurídicos de normas modificadas ou suprimidas. Trata-se de 
garantia ocupada com os efeitos concretos da lei. Não se destina a inibir a evolução da legislação, a modificação ou a revogação das leis preexistentes, mas a fazer perdurar os efeitos individuais e concretos da lei alterada ou suprimida mais vantajosa na nova ordem legal. Direitos adquiridos são direitos subjetivos estabilizados no patrimônio jurídico individual e protegidos da aplicação da lei nova. Não são direitos vocacionados a impedir a inovação abstrata da lei. Na verdade, a garantia do direito adquirido pressupõe, como condição para ser aplicada, a efetiva ocorrência de processos de reforma legislativa. Se não há sucessão legislativa, modificação da norma jurídica anterior por norma superveniente mais gravosa, a garantia não tem oportunidade de incidir.

A garantia do direito adquirido funciona, no tempo, como um guarda-chuva. Não impede a aplicação geral e imediata da lei nova. Resguarda, no entanto, os indivíduos que titularizam uma situação jurídica vantajosa anterior da aplicação das novas disposições legais. Estes indivíduos seguem regidos pela regra alterada ou revogada, mais vantajosa, para certos e determinados efeitos, embora a norma nova seja desde logo aplicável aos demais indivíduos. Trata-se de uma garantia individual, que funciona como tal, pois tutela a situação subjetiva de um ou mais indivíduos determinados. Não funciona como um dique das reformas legislativas, não represa nem pode conter a alteração abstrata da lei, porque a sua função é apenas prolongar em concreto a aplicação da norma mais vantajosa, revogada ou modificada por lei sucessiva (tecnicamente, garantir a ultra-atividade ou a eficácia protraída da norma preexistente), porém apenas para os indivíduos que incorporaram em seu patrimônio individual a situação jurídica anterior.

Trata-se de garantia que opera no plano dos efeitos jurídicos, no plano concreto das relações jurídicas, não no plano lógico abstrato das normas jurídicas. Não diz ordinariamente respeito à validade da alteração normativa, mas aos seus efeitos. Ao se alterar a norma abstrata não se fere direito adquirido, menos ainda a norma de sua garantia, desde que a nova norma abstrata não recuse expressamente a garantia do direito adquirido a certo grupo de indivíduos que efetivamente os titularizem. $O$ direito adquirido apenas manifesta o seu vigor e imutabilidade no plano concreto, face a alguma interferência inovadora do legislador. Este fato produz consequêencias que o intérprete, inclusive no Poder Legislativo, não pode desconsiderar.

\section{Conseqüência Processual}

A primeira e mais importante conseqüência diz respeito a impossibilidade de impugnação ou questionamento da validade da lei nova, na via abstrata de controle da constitucionalidade, sob o fundamento de violação da garantia do direito adquirido, desde que a lei não determine expressamente sua incidência sobre situações anteriores.

No SUPREMO TRIBUNAL FEDERAL esse entendimento ficou assentado de modo expresso em decisão relatada pelo Min. SEPÚLVEDA PERTENCE, no curso de vigência da atual Constituição de 1988, mais precisamente a ADIN 1161-8-DF (DJ 02-01-1995, p.446). Segundo o acórdão, a questão sobre violação de direito adquirido "não é susceptível de deslinde na via do controle abstrato: salvo quando a própria lei determina sua incidência sobre situaçōes anteriores (v.g., ADIN 493, 
Med. Cautelar, M. ALVES, 7.5.91, RTJ 142/52), a impugnação não diz com a validade da lei, mas com a sua eficácia no tempo e há de ser dirimida pela via difusa adequada, por provação dos prejudicados (vg. ADIN 174, PERTENCE, 21.3.90, RTJ 131/498; ADIN 613, RESEK, 29.4.93)".

No mesmo sentido, com enunciado didático, registra a ementa da ADIN $\mathrm{n}$. 1434-SP, Relator Min. CELSO DE MELLO (DJ 22-11-96, p. 45.684):

“(...) O controle normativo de constitucionalidade qualifica-se como típico processo de caráter objetivo, vocacionado exclusivamente à defesa, em tese, da harmonia do sistema constitucional. A instauração desse processo objetivo tem por função instrumental viabilizar o julgamento da validade abstrata do ato estatal em face da Constituição da República. O exame de relações jurídicas concretas e individuais constitui matéria juridicamente estranha ao domínio do processo de controle concentrado de constitucionalidade.

A tutela jurisdicional de situações individuais, uma vez suscitada a controvérsia de índole constitucional, há de ser obtida na via do controle difuso de constitucionalidade, que, supondo a existência de um caso concreto, revela-se acessivel a qualquer pessoa que disponha de interesse e legitimidade (CPC, art.39)(...)".

Confira-se ainda, adotando a mesma orientação, no âmbito da jurisprudência do SUPREMO TRIBUNAL FEDERAL, a Rp. 891-GB e Rp. 895, rel. Min. DJACI FALCÃO, 13-6-73, RTJ 67/327 e 68/283, bem assim a Rp. 1.288-DF, rel. Min. RAFAEL MAYER, RTJ $119 / 548$.

Essa orientação jurisprudencial, ao situar o tema da tutela dos direitos adquiridos no plano adequado, aplica-se perfeitamente também para o controle abstrato da validade de projeto de lei perante as COMISSÕES DE CONSTITUIÇÃO E JUSTIÇA DA CÂMARA E DO SENADO FEDERAL. Neste âmbito, por igual, parece deslocado e impróprio apreciar a questão da eficácia ou aplicação concreta futura do projeto, a sua eventual aplicabilidade ou inaplicabilidade imediata a todas as situações existentes, pois a missão precípua deste tipo de controle resume-se em avaliar se ocorre direta compatibilidade ou incompatibilidade do texto apreciado face à Constituição.

\section{Conseqüência material}

A segunda consequiência dessa clara separação de esferas lógicas (plano da validade/plano da norma abstrata e plano dos efeitos/plano das situações jurídicas individuais), é evidenciar a confusão muito comum entre direitos adquiridos e garantia dos direitos adquiridos diante do poder de reforma constitucional.

Os direitos adquiridos consubstanciam-se em situações jurídicas individuais concretas; a garantia dos direitos adquiridos apresenta-se como norma constitucional geral e abstrata. Os primeiros são incontáveis, de número incerto, consolidando-se no patrimônio individual a partir da implementação de atos jurídicos individuais (v.g., atos administrativos ampliativos da esfera jurídica de particulares, como licenças e autorizaçōes), atos negociais, fatos jurídicos (v.g., transcurso do tempo para aquisição do direito à aposentadoria) ou declarações legislativas (v.g, anistias) e podem tanto encontrar fundamento na Constituição quanto em leis ordinárias. A garantia do direito adquirido, de outra parte, é norma geral e abstrata, expressamente 
contemplada na Constituição Federal. Os direitos adquiridos situam-se no plano dos direitos subjetivos; a garantia dos direitos adquiridos insere-se no plano do direito objetivo. A distinção tem reflexos diretos na questão dos limites do poder de reforma constitucional.

\section{Direitos adquiridos e reforma constitucional: a questão das cláusulas pétreas}

Os direitos adquiridos não são cláusula pétrea da Constituição e sim a garantia dos direitos adquiridos, isto é, a norma enunciada no art. 5o, XXXVI, do texto constitucional, inscrita no Título dos Direitos e Garantias Fundamentais. Esta norma não pode ser suprimida do estatuto constitucional mediante o exercício do poder de emenda.

As cláusulas pétreas, também chamadas cláusulas de imutabilidade ou garantias de eternidade, são limites materiais ao poder de reforma constitucional. Referem a conteúdos, princípios, normas constitucionais que não podem ser objeto de deliberação pelo poder de reforma constitucional. Dizem respeito a normas que constam da Constituição e não a situações jurídicas concretas titularizadas pelo Poder Público ou por particulares. Revestem-se de eficácia reforçada, na medida em que denotam normas constitucionais que somente podem ser derrogadas pelo poder constituinte originário. Constituem exceção ao poder de reforma constitucional e, como tais, reclamam interpretação estrita. Sintetizam a idéia fundamental de direito da coletividade, compondo a identidade básica da Constituição. Reformá-las é inviável para os órgãos constitucionais instituídos, pois significaria o mesmo que a retirada dos alicerces que os sustentam e a derrubada da Constituição.

As cláusulas pétreas são normas eminentíssimas da ordem constitucional. O seu conceito não pode ser trivializado ou banalizado. A garantia de imutabilidade qualificada que possuem frente ao poder de reforma constitucional não pode ser transferida para situações jurídicas individuais ou para normas infraconstitucionais, enunciadas em leis ordinárias ou até em atos normativos inferiores. $\mathrm{Na}$ ordem constitucional, cumprem uma tarefa especialíssima: a função de bloqueio em relação a toda e qualquer alteração do estatuto fundamental. As cláusulas pétreas, por isso, não podem ser em número incerto, incontável, a ponto de instalar uma situação de imutabilidade de parcela significativa da ordem jurídica. Situam-se logicamente apenas na intimidade da Constituição, de forma expressa ou implícita, são em número limitado e referem apenas a normas constitucionais.

Não falta quem pense diversamente. Com respeito aos que assim entendem, pensar que o poder de reforma está condicionado a respeitar todo e qualquer direito adquirido é subverter a hierarquia das normas no sistema jurídico. $O$ sistema jurídico estrutura-se em camadas sucessivas de normas, fundamentando-se as normas inferiores nas normas do estrato superior. No topo do sistema está a Constituição e na base estão as normas individuais. $O$ sistema jurídico é comumente descrito como uma pirâmide. Na medida em que se desce do topo da pirâmide para a base, da Constituição para as normas individuais, aumenta o número de normas e os limites e condicionamentos materiais ao órgão competente para edição de novas normas. 
Reversamente, na medida em que se sobe da base da pirâmide jurídica em direção ao seu vértice diminui o número de normas e o número das limitações materiais ao órgão competente para alterar as normas existentes. Assim, o administrador que decide um caso concreto está limitado, em termos de conteúdo, por regulamentos, pela lei (ordinária ou complementar) e pela Constituição; o legislador, que edita lei ordinária, encontra-se limitado, em termos materiais ou de conteúdo, por toda a Constituição; o poder de reforma constitucional, por sua vez, diz-se limitado quanto ao conteúdo do seu objeto apenas pelas cláusulas pétreas expressas ou implícitas constantes da própria Constituição.

Os que defendem que a garantia do direito adquirido não é somente dirigida ao legislador ordinário e sim também ao poder de reforma constitucional esquecem a lógica que rege este sistema. Se o direito adquirido, qualquer que seja a sua fonte, como situação jurídica individual, for oponível também em face da Constituição, ou de emenda que a modifique, o poder de reforma estará submetido a limites materiais semelhantes ao do legislador ordinário, contido segundo quase o mesmo grau de condicionamento, quando toda a lógica do sistema aponta para menores condicionamentos e maior liberdade de iniciativa quanto ao conteúdo possível de alteração. No sistema jurídico nacional, lei e emenda constitucional são entidades claramente distintas. A lei é veículo ordinário de expressão normativa, irrompe com certa agilidade no processo legislativo, mas encontra ampla delimitação material fornecida pela Constituição. A emenda, de revés, é veículo normativo extraordinário, episódico, de dificílima produção no plano processual, mas, em contraponto, dotado de maior abertura no campo material, pois está limitado apenas pelas "cláusulas pétreas" previstas na própria Constituição. $O$ poder de reforma constitucional, recorde-se, embora não se confunda com o poder constituinte originário (força políticasocial incondicionada em termos jurídicos e fixadora de uma nova idéia fundamental de direito), expressa também de forma especial ou incomum a soberania popular través do Parlamento, uma vez que opera apenas após quatro votações sucessivas de plenário, duas em cada casa legislativa, observado um quorum qualificado de três quintos na Câmara dos Deputados e no Senado da República.

Os autores que defendem que a garantia do direito adquirido é também limite à eficácia do poder de reforma dizem que a palavra "lei", empregada expressamente no enunciado do art. 5o, XXXVI, da Constituição Federal, não é somente dirigida ao legislador ordinário e sim também ao poder de reforma constitucional. A Constituição, lembram, é também uma lei. Ninguém o contesta. Porém, o que se esquece de mencionar é que o SUPREMO TRIBUNAL FEDERAL, a quem cabe a última palavra em matéria de interpretação constitucional, entende que a palavra "lei" no art. 5, XXXVI, da Constituição de 1988, constante também de normas semelhantes de Constituições anteriores, vem empregada na Constituição em sentido formal, colhendo apenas ao legislador infraconstitucional. A Constituição é lei em sentido material; em sentido formal, excede às leis ordinárias, gozando de supra-legalidade, vale dizer, eficácia inaugural e sobranceira na ordem jurídica. A Constituição não conhece limites anteriores ou posteriores aos constantes dos seus próprios comandos. Disto se vale a Constituição tanto para atribuir quanto para retirar a base de validade de disposições legislativas ordinárias e limitar ou ampliar situações jurídicas indivi- 
duais, não ficando de modo algum condicionada pelas normas infraconstitucionais que the desdobram o conteúdo, sejam ou não declaratórias de direitos ou obrigações. Esse fato vincula-se também ao caráter político eminente das normas constitucionais. Presume-se que as normas constitucionais condensam a vontade fundamental da nação, o interesse público em seu sentido mais amplo, as aspirações coletivas mais densas, frente às quais não caberia perpetuar situações individuais mais vantajosas.

Contra a Constituição inexiste o princípio do direito adquirido e, tampouco, o princípio da irretroatividade. As normas constitucionais não apenas incidem imediatamente (o que se presume, salvo inequívoca disposição em contrário), como é-lhes permitido retroagir, para alcançar "efeitos passados de fatos passados", nesse último caso desde que se faça a ressalva mediante declaração expressa. A regra é a imediatidade eficacial das normas jurídicas constitucionais. Se se deseja manter no tempo, ou por certo tempo, a aplicação de normas anteriores contrárias a novo mandamento constitucional, exige-se norma de transição expressa. Se o objetivo é a aplicação do novo dispositivo constitucional também para alterar no passado efeitos jurídicos já consolidados, a mesma exigência de explicitude é feita.

Essas afirmações são quase um truísmo, quando observados princípios elementares do direito. Se a Constituição é a norma fundamental do sistema jurídico, base de validade de todas as demais normas, é evidente que não pode admitir a existência de qualquer direito altaneiro, anterior ou superior a ela mesma, sob pena de perder a condição de norma inicial e fundante do sistema jurídico nacional. A legislação infraconstitucional permanece válida apenas se não confronta com o estatuto constitucional (princípio da recepção). Se a legislação conflita, prevalece a Constituição, norma hierárquica superior do sistema jurídico (princípio da supremacia). Por isso a eficácia da Constituição é imediata, e se presume tal, salvo disposição expressa em contrário constante da própria Constituição (princípio da eficácia imediata da Constituição).

Essas noções não nos devem conduzir, porém, a confundir a garantia do direito adquirido com o princípio da irretroatividade da lei. Retroagir (retro agere) é incidir sobre o passado, é atribuir nova valoração jurídica a fatos resolvidos no tempo, regredindo ao pretérito. É verdade que, no Brasil, a Constituição não proíbe de forma absoluta e genérica a retroeficácia da lei. A Constituição brasileira proíbe a retroatividade da lei penal incriminadora (Art. $5^{\circ}, \mathrm{XL}$ ) e prescreve que a lei não poderá retroagir para ferir o direito adquirido, $o$ ato jurídico perfeito ou a coisa julgada (Art. $5^{\circ}, \mathrm{XXXVI)}$. Não impede a retroação feita para beneficiar, mas, ao contrário, a admite expressamente ("A lei penal não retroagirá, salvo para beneficiar o réu" - Art. 52, XL) e implicitamente ("Sem prejuízo de outras garantias asseguradas ao contribuinte, é vedado à União, aos Estados, ao Distrito Federal e aos Municípios: (...) IIIcobrar tributos: a) em relação a fatos geradores ocorridos antes do início da vigência da lei que os instituiu ou aumentou; b) no mesmo exercício financeiro em que haja sido publicada a lei que os instituiu ou aumentou - Art. 150, III, "a" e "b"). Tampouco repele a retroação de lei quando não estiver em causa dano a direito adquirido, ato jurídico perfeito ou coisa julgada. Ressalte-se ainda que a Constituição abre autorização expressa à retroação, quando se tratar de inovação jurídica promovida por medida provisória não convertida em lei, pois neste caso a alteração promovida com força de lei perde a eficácia, desde a edição da medida provisória, 
devendo o Congresso Nacional disciplinar as relações juridicas delas decorrentes (Art. 62, parágrafo único). E, ademais, para algumas questões, permitiu a retroação inclusive para prejudicar o beneficiário de direito (Art. 51, do ADCT: - "Serão revistos pelo Congresso Nacional, através de Comissão mista, nos três anos a contar da data da promulgação da Constituição, todas as doações, vendas e concessōes de terras públicas com área superior a três mil hectares, realizadas no periodo de $1^{0}$ de janeiro de 1992 a 31 de dezembro de 1987').

Em contraste, há apenas uma única hipótese em que a Constituição Federal expressamente afasta a aplicação da garantia do direito adquirido contra si e contra a lei ordinária. Esta disposição encontra-se no art. 17 do ADCT, nos seguintes termos: "Os vencimentos, a remuneração, as vantagens e os adicionais, bem como os proventos de aposentadoria que estejam sendo percebidos em desacordo com a Constituição serão imediatamente reduzidos aos limites dela decorrentes, não se admitindo, neste caso, invocação de direito adquirido ou percepção de excesso a qualquer título". Ora, consoante o inciso XI do art. 37 da Constituição, "a lei fixará o limite máximo e a relação de valores entre a maior e a menor remuneração dos servidores públicos". Certo, a lei referida não é absolutamente livre, pois deve observar também "limites máximos" definidos no âmbito dos respectivos Poderes desde logo pela Constituição: "os valores percebidos como remuneração, em espécie, a qualquer título, por membros do Congresso Nacional, Ministros de Estado e Ministros do Supremo Tribunal Federal e seus correspondentes nos Estados, no Distrito Federal e nos Territórios, e, nos Municípios, os valores percebidos como remuneração, em espécie, pelo Prefeito". Porém, é evidente que a lei prevista não é obrigada a reproduzir os limites máximos já constantes da Constituição. Se assim fosse, a previsão da lei no dispositivo constitucional seria ociosa e contraditória. Tem-se, por isso, que o preceito do art. 37, XI, da Constituição Federal encerra a previsão de dois limites de remuneração: um limite a ser fixado pela lei e um limite fixado para a lei. Quando a lei ordinária fixa o limite máximo de remuneração em valor abaixo do máximo admitido pela Constituição, diz-se que estabeleceu um redutor ou subteto.

Na jurisprudência do SUPREMO TRIBUNAL FEDERAL e do SUPERIOR TRIBUNAL DE JUSTIÇA, embora não se isole com clareza os dois tipos de limites de remuneração, aplica-se a ambos o comando do art. 17 do ADCT. Neste sentido, confira-se, no SUPREMO TRIBUNAL FEDERAL, o RE-167844/SP, Rel. Min. ILMAR GALVÃO, 22/11/1994, DJ 04-08-95, pp.22.518; e, no SUPERIOR TRIBUNAL DE JUSTIÇA, o MS 2.306-5-DF, Rel. Min. JESUS COSTA LIMA, 2/9/I993, R. Sup. Trib. Just., a.6, (56), 1994, p. 69; RMS n. 1.679-PR, Rel. Min. MILTON LUIZ PEREIRA, DJ de 13/12/1993, p. 37.403; MS 2450-DF, Rel. Min. ADHEMAR MACIEL, j. em 08-05-1996, DJ 02/06/1997, p. 23.750; RESP 0113698-SC, Rel. Min. VICENTE LEAL, j. em 24-06-1997, DJ 01/09/1997, p. 40.897.

Esta dualidade na aplicação ou a dupla eficácia do art. 17 do ADCT explica porque a Constituição de 1988 apenas neste artigo expressamente recusou a invocação e tutela dos direitos adquiridos. Neste caso, apenas neste caso, além da própria Constituição, também a lei ordinária ficou autorizada a desconsiderar "direitos adquiridos". Nos demais casos, quando a própria norma constitucional tratou dire- 
tamente de alterar ou suprimir vantagem, a Constituição dispensou a advertência e a cautela enunciada no art. 17 do ADCT, adotando como princípio implícito o princípio da supremacia e o da eficácia imediata das disposições constitucionais.

O que vem de ser dito evidencia o equívoco de confundir o tema dos direitos adquiridos, que não diz respeito ao passado, mas a efeitos presentes de fatos passados, com a questão da irretroatividade da lei, que diz respeito à alteração no passado de efeitos realizados ou consumados. As duas questões colocam problemas diferentes e recebem soluções técnicas distintas: (a) a aplicação direta e imediata de norma constitucional sobre relaçōes jurídicas nascidas no regime anterior e que permanecem sob a vigência da nova Constituição ou disposição constitucional e (b) a aplicação de nova disposição constitucional a fatos e relaçōes jurídicas resolvidas antes da vigência da nova norma. Na primeira questão trata-se de indagar sobre a manutenção no novo regime constitucional de direitos adquiridos no regime anterior. Na segunda, interroga-se pela aplicação retroativa da norma constitucional. As soluções técnicas não coincidem. Para a primeira indagação, basta apurar a compatibilidade da regra precedente infraconstitucional com a nova regra constitucional. Havendo compatibilidade, o direito precedente é recepcionado pela nova ordem constitucional. Havendo contrariedade lógica, prevalece a norma constitucional, pois trata-se de norma que ocupa posição hierárquica superior e, ademais, inaugural do sistema jurídico. A revogação, a supressão do direito precedente, nesse caso, independe de declaraçāo expressa da norma constitucional. A revogação pode ser implícita, por simples constatação do conflito lógico das referidas normas na regulação do mesmo instituto. $\mathrm{Na}$ segunda questão, de revés, a solução depende de existir ou inexistir declaração expressa na norma constitucional autorizando a retroeficácia do preceito constitucional. Havendo a autorização, a retroação é possivel; não havendo, deve ser recusada, pois não se presume e é medida excepcional.

As considerações anteriores não são puramente acadêmicas. São inúmeros os acórdãos do SUPREMO TRIBUNAL FEDERAL que afirmam expressamente ser inadmissível opor direito adquirido a normas da Constituição Federal, resultem ou não de emendas constitucionais. Podem ser referidos alguns, anteriores e posteriores à Constituição de 1988.

Decisões anteriores à Constituição de 1988:

"Magistrado. Incidência imediata da proibição contida no artigo 114, I, da Constituição Federal na redação dada pela Emenda Constitucional n $27 / 77$. - Não há direito adquirido contra texto constitucional, resulte ele do Poder Constituinte originário, ou do Poder Constituinte derivado. Precedentes do STF. Recurso extraordinário conhecido e provido." (STF, RE $\mathrm{n}^{2}$ 94.414-SP, Rel. Min. MOREIRA ALVES, RTJ 114/237, RDA 160/144, j. em 13/02/1985).

“A norma da Emenda Constitucional no8/77, que estabeleceu o prazo máximo de quatro anos para validade de concursos, tem aplicação imediata. - Não há como invocar, contra essa norma, as garantias do direito adquirido que se dirigem à lei ordinária e não à Constituição" (STF, RE n. 95175, Rel. Min. SOARES MUNOZ, RDA /123, j. em 20.04.1982).

“(...) O direito adquirido, garantido no $\$ 3^{\circ}$ do Art. 153 da Constituição Federal, somente é oponivel à lei. Contra a própria Constituição não há direito adquirido. (...)" (STF, Pleno, Representação n. 895, Rel. Min. DJACI FALCĀO, RTJ 67/327). 
“(...) Contra preceito constitucional não é invocável o direito adquirido" (STF, $2^{\mathrm{a}}$ Turma, RE n. 14.360, Rel. Min. EDGAR COSTA, RF, abril, 1951, p. 423).

"Não há direito adquirido à acumulação remunerada, porque não há direito adquirido depois da Constituição" (STF, Rel. Min. CÂNDIDO MOTTA FILHO, RTJ 42/345, j. em 17/03/1967).

"Não há direito adquirido contra preceito expresso da Constituição. A correlação de matérias, para efeito de acumulação remunerada, é exigida quando ambos os cargos são do magistério." (STF, RE n. 35.491-SP, Rel. Min. LUIZ GALLOTTI, RDA 54/215, j. 30/10/1958)

“(...) A Emenda Constitucional $n .8 / 77$, ficou em quatro anos o prazo de validade dos concursos (art. 97, $\$ 3^{\circ}$, da Constituição Federal). - Trata-se de regra imperativa, que incide imediatamente por força de sua natureza constitucional. - Inocorrência de direito adquirido contra a Constituição. Precedentes: MS 20.157, Pleno, RTJ 95/51. RE não conhecido" (RE n. 93.290-RJ, Rel. Min. CORDEIRO GUERRA, RTJ 99/869, j. em 28/08/1981).

"(...) Quando sucede alteração constitucional que modifique a estrutura de um instituto jurídico, não se tem como admitir a persistência das leis ordinárias que se encontrem a contraditar a nova estrutura, pois, no pormenor, $\dot{e}$ a vontade inovadora do constituinte que prevalece. Recurso extraordinário provido." (STF, RE n. 84.797SP, Rel. Min. ANTONIO NEDER, RTJ 80/944, j. em 10/08/1976).

“(...) Inexistência de direito adquirido a regime jurídico do servidor público cuja modificação decorre de texto constitucional" (STF, RE n 100.144-SP, Rel. Min. MOREIRA ALVES, RTJ 109/1175, j. em 7/07/83).

“(...) $O \$ 3^{\circ}$ do art. $153 \mathrm{da} C \mathrm{CF}$ impede que a lei prejudique o direito adquirido, mas não que a própria Constituição regule, como lhe parecer, a eficácia temporal de concursos futuros ou já realizados, inclusive mediante emenda, como aconteceu, no caso, a de $n^{2}$ 8, de 1977, ao acrescentar o $\$ 3^{\circ}$ do art. 97' (STF, AR n 1.212, Rel. Min. SYDNEY SANCHES, RDA 174/183, j. em 3/09/1987).

Decisões do STF posteriores à Constituição de 1988

“(...) A supremacia juridica das normas inscritas na Carta Federal não permite. ressalvadas as eventuais exceções proclamadas no próprio texto constitucional, que contra elas seja invocado o direito adquirido. Doutrina e jurisprudência." (STF, ADIN 248-RJ, Pleno, Rel. Min. CELSO DE MELLO, RTJ 152/341, j. em 18/11/1993).

"Transformação de cargo de datilógrafo em técnico de planejamento, por desvio de função. Alegação de direito adquirido contra a Constituição. (....). Não há direito adquirido contra a Constituição. Recurso extraordinário conhecido e provido." (STF, 1 1 Turma, RE 157.538-RJ, Rel. Min. MOREIRA ALVES, RTJ 151/992, j. em 22/07/1993).

"(...) O constituinte, ao estabelecer a inviolabilidade do direito adquirido, do ato jurídico perfeito e da coisa julgada, diante da lei (art. 5o, XXXVI), obviamente, excluiu-se dessa limitação, razão pela qual nada o impedia de excluir, dessa garantia, a situação jurídica em foco. - Assim é que, além de vedar, no art. 37, XIV, a concessão de vantagens funcionais "em cascata", determinou a imediata supressão de excessos da espécie, sem consideração a "direito adquirido", expressāo que há 
de ser entendida como compreendendo, não apenas o direito adquirido propriamente dito, mas também o decorrente de ato jurídico perfeito e da coisa julgada. (...). Inconstitucionalidade não configurada. Recurso não conhecido. “ (STF, RE 140894, Rel. Min. ILMAR GALVÃO, DJ 09-08-1996, PP-27102, j. em 10/05/1994).

“(...) O disposto no artigo 5 , XXXVI, da Constituição Federal se aplica a toda e qualquer lei infraconstitucional, sem qualquer distinção entre lei de direito publico e lei de direito privado, ou entre lei de ordem publica e lei dispositiva. Precedente do S.T.F (...)( STF, Tribunal Pleno, ADIN 493-DF, Rel. Min. MOREIRA ALVES, RTJ 143-03/724, j. em 25/06/1992).

"Pensōes especiais vinculadas a salário mínimo. Aplicação imediata a elas da vedação da parte final do inciso IV do artigo 7 da Constituição de 1988. - Já se firmou a jurisprudência desta Corte no sentido de que os dispositivos constitucionais tem vigência imediata, alcançando os efeitos futuros de fatos passados (retroatividade mínima). Salvo disposição expressa em contrario - e a Constituição pode faze-lo - eles não alcançam os fatos consumados no passado nem as prestações anteriormente vencidas e não pagas (retroatividades máxima e media). - Recurso extraordinário conhecido e provido.(STF, Primeira Turma, RE-140499-GO, Rel. Min. MOREIRA ALVES, DJ DATA-09-09-94/PP-23444, j. em 12/04/1994)

“(...) Não há dúvida de que a Constituição se aplica de imediato, alcançando os efeitos futuros de fatos passados (retroatividade mínima), como sucede com a alteração da competência, mas, a menos que o declare expressamente, não desconstitui os fatos consumados no passado (retroatividade máxima), como é o caso da preclusão já ocorrida anteriormente. (...) (STF, Primeira Turma, RE-136926-DF, Rel. Min. MOREIRA ALVES, DJ DATA-15-04-94 PP-08062, j. em 16/11/1993).

“(...). A vedação da vinculação do salário mínimo, constante do inc. IV do art. $7^{\mathfrak{2}}$ da Carta Federal, que visa impedir a utilização do referido parâmetro como fator de indexação para obrigações, aplica-se imediatamente sobre as pensões que anteriormente foram estipuladas, não havendo que se falar em direito adquirido. Recurso extraordinário conhecido e provido" (STF, RE n. 143812-6-GO, Rel. Min. ILMAR GALVÃO, j. em 27/08/1996).

Decisões posteriores a 1988 no STJ

“Mandado de Segurança. Servidor público. Acumulação de cargos. Constituição Federal de 1988. Direito adquirido. Inexistência. Inexiste direito adquirido contra o texto constitucional, em especial no que se refere a regime jurídico de servidores públicos. Precedentes do STF. - Impossibilidade de se entender estável o servidor que incida em acumulação de cargos, vedada constitucionalmente." (STJ, Mandado de Segurança ne 7-DF, Rel. Min. MIGUEL FERRANTE, R. Sup. Trib. Just. 2(7)/pp.173, 1990, j. em 12/12/1989)

“ (...) Não se há de invocar direito adquirido contra o que posto induvidosamente na nova ordem constitucional, em modificação não apenas do texto mas do próprio sistema, até porque as garantias do direito adquirido se dirigem à lei ordinária e nào à Constituição.(...)"(STJ, Rec. Esp. n² 506 - RJ, Rel. Min. SÁLVIO DE FIGUEIREDO, R. Sup. Trib. Just., Brasília, 2(06)/pp. 360, 1990, j. em 25/09/1989).

“(...) Não há como invocar direito adquirido contra a Constituição e, se o problema da remuneração dos militares - como da maioria dos brasileiros assala- 
riados - reclama soluções, não cabe ao Poder Judiciário, que não tem função legislativa, aumentar vencimentos" (STJ, MS n. 834-DF, Rel. Min. HÉLIO MOSIMANN, R. Sup. Trib. Just., a4 (29), p. 191-2).

$\mathrm{Na}$ doutrina jurídica nacional, por igual, é amplamente majoritário o tratamento da garantia dos direitos adquiridos como norma dirigida exclusivamente ao legislador infraconstitucional, aos administradores e aos magistrados. Neste sentido, confira-se, entre as publicações mais recentes, PINTO FERREIRA, Comentários à Constituição Brasileira, Saraiva, 1989, v. 1, pp.148/149; CELSO RIBEIRO BASTOS, Comentários à Constituição do Brasil, Saraiva, Vol 2, 1989, p. 191; JOSÉ EDUARDO MARTINS CARDOZO, Da Retroatividade da Lei, São Paulo, Ed. RT, 1995, p. 313-4; CÁRMEM LÚCIA ANTUNES ROCHA,"O Princípio do Direito Adquirido no Direito Constitucional", Separata da Revista de Informação Legislativa, a.26, n. 103., jul./set., 1989, p. 156; HUGO DE BRITO MACHADO, "Direito Adquirido e Coisa Julgada como Garantias Constitucionais", Revista dos Tribunais, a.84, Vol. 714, abril, 1995, p. 21-2; PAULO ROBERTO MENDONÇA SILVÉRIO, "O Instituto Jurídico dos Direitos Adquiridos e a cláusula pétrea dos direitos e garantias individuais", Revista de Informaçāo Legislativa, a.32, n. 128., out./dez., 1995, p. 77 e, entre os clássicos, CARLOS MAXIMILIANO, Direito Intertemporal ou Teoria da Retroatividade das Leis, Rio de Janeiro, p. 325, item 280; BENTO DE FARIA, Aplicação e Retroatividade da Lei, Rio de Janeiro, 1934, n 8, p. 25 e ss.; PONTES DE MIRANDA, Comentários à Constituição de 1967, com a Emenda n. 1, de 1969. $3^{\text {a }}$ ed., Rio de Janeiro, Forense, 1967, p. 392 e 394; WILSON DE SOUZA CAMPOS BATALHA, Direito Intertemporal, Rio de Janeiro, Forense, 1980, p. 438.

A menção a esses autores e julgados patenteia o equívoco de se tentar impor ao poder de reforma constitucional, por via interpretativa, limite que não lhe foi colocado pelo poder constituinte originário e que destoa da eminência e da função própria do poder de reforma constitucional. Na verdade, ampliar o grau de rigidez da Constituição, pela via de construir uma interpretação ampliativa das cláusulas pétreas, ao contrário de servir para preservar a Constituição e acautelar ao limite máximo o princípio da segurança jurídica, significa estimular aventuras constitucionais mais abrangentes, completas, incondicionadas, pela via de convocação de novas constituintes ou novas assembléias revisoras mediante consulta direta ao titular da soberania. São propostas hermenêuticas que desprestigiam a representação popular e as vias democráticas normais de deliberação e alteração do estatuto fundamental, colocando em risco a própria adaptação do texto constitucional a novas exigências coletivas.

\section{Direito adquirido e alteração abstrata do regime jurídico dos servidores públicos}

É pacífica a jurisprudência dos tribunais superiores quanto à inexistência de direito adquirido a regime jurídico por parte dos servidores públicos ocupantes de cargo público. Diz-se, nestes casos, que a relação jurídica que o servidor mantém com o Estado é legal ou estatutária, ou seja, objetiva, impessoal e unilateralmente 
alterável pelo Poder Público. A disciplina geral da função pública é considerada inapropriável pelo servidor público e, portanto, tida como sujeita a modificação com eficácia imediata tanto no plano constitucional quanto infraconstitucional.

O tema é complexo e obriga a recordar noções fundamentais sobre a função pública. Na doutrina, por todos, confira-se a lição sintética e precisa de CELSO ANTÔNIO BANDEIRA DE MELLO sobre o tema:

"Em tempos, pretendeu-se que o vínculo jurídico entre o Estado e o funcionário fosse de natureza contratual. De início, entendido como contrato de direito público, afinal, prevaleceu o entendimento correto, que nega caráter contratual à relação e afirma-lhe natureza institucional.

Isto significa que o funcionário se encontra debaixo de uma situação legal, estatutária, que não é produzida mediante um acordo de vontades, mas imposta unilateralmente pelo Estado e, por isso mesmo, suscetível de ser, a qualquer tempo, alterada por ele sem que o funcionário possa se opor à mudança das condições de prestação de serviço, de sistema de retribuição, de direitos e vantagens, de deveres e limitações, em uma palavra de regime jurídico." (Regime Constitucional dos Servidores da Administração Direta e Indireta, 2a ed., revista, atual., São Paulo, Ed. RT, 1991, p. 19).

Na jurisprudência do SUPREMO TRIBUNAL FEDERAL é abundante a coleção de acórdãos que adotam a mesma orientação de recusar a existência de direito adquirido a regime jurídico pelos servidores públicos estatutários. Podem ser referidas alguns julgados:

"Constitucional Funcionário Público. Regime de tempo integral. Pela natureza estatutária das relações do funcionário público com a Administração, pode tal regime ser modificado por lei, sem que isto ofenda o principio constitucional da garantia ao direito adquirido" (STF, RE 99.592, Rel. Min. DÉCIO MIRANDA, RTJ 108/382, j. em 7/10/1983).

“A garantia constitucional do direito adquirido não faz intangivel o regime juridico de um servidor do Estado, sujeito ao estatuto especial ante a edição da lei complementar que o modifica" (STF, RE 99.594, Rel. Min. FRANCISCO REZEK, RTJ 108/785)

"Funcionalismo. Proventos de aposentadoria. Se a lei extingue vantagem ou gratificação que serviu de base ao cálculo de proventos do funcionário aposentado, sem redução dos mesmo, não há ofensa a direito adquirido, uma vez que a garantia constitucional não abrange o regime jurídico" (STF, RE 99.955, Rel. Min. CARLOS MADEIRA, RTJ 116.1065).

"Lei nova, ao criar direito novo para o servidor público, pode estabelecer, para o cômputo do tempo de serviço, critério diferente daquele determinado no regime jurídico anterior. - Não há direito adquirido a regime jurídico" (S.T.F, R.E n. 99.522, Rel. Min. MOREIRA ALVES, RDA 153/110-113, j. em 1/03/1983).

"O funcionário tem direito adquirido a, quando se aposentar, ter seus proventos calculados em conformidade com a lei vigente ao tempo em que preencheu os requisitos para a aposentadoria. - Não possui, contudo, direito adquirido ao regime jurídico relativo ao cargo, o qual pode ser modificado por lei posterior. - (...) (S.T.F, R.E. n. 92.638, Rel. Min. MOREIRA ALVES, RDA 145/56-61, j. em 6/06/1980). 
"Vencimentos: reajuste: direito adquirido Inexistência. Segundo a jurisprudência do STF - que reduz a questão à inexistência de direito adquirido a regime juridico -, as leis ainda quando posteriores à norma constitucional de sua irredutibilidade - que modificam sistemática de reajuste de vencimentos ou proventos são aplicáveis desde o início de sua vigência. Ressalva do entendimento do relator, expresso no julgamento do MS 21.216.(Gallotti, RTJ 134/1.112)"(STF, R.E. n. 185.966-1, Rel. Min. SEPÚlVEDA PERTENCE, DJU de 22.09.1995, Seção I., p.30.632).

"Decreto-Lei n 2.335/87. Plano Verão. Reajuste de 26,05\%. Direito adquirido. Inconstitucionalidade. 1- O Plenário da Corte reiterou o entendimento de que não há direito adquirido a vencimentos de funcionários públicos, nem direito adquirido a regime jurídico instituido por lei. Em se tratando de norma de aplicação imediata, esta não alcança vencimentos já pagos, ou devidos "pro labore facto" (...)" (STF, RE-199753-MG, Rel. Min. MAURÍCIO CORREIA, DJU de 07-06-1996, pp. 19.843, j. em 30/04/1996).

No SUPERIOR TRIBUNAL DE JUSTIÇA, de outra parte, orientação idêntica é adotada nos seguintes acórdãos:

"(...) O regime público estatutário, que disciplina o vínculo entre o servidor público e a Administração, não tem natureza contratual, em razão do que inexiste direito a inalterabilidade do regime remuneratório, sendo passível de modificação quando em desacordo com a ordem constitucional. (...).(STJ, ROMS 6756-PB, Sexta Turma, Rel. Min. VICENTE LEAL, DJ 18/11/1996, p. 44.928, j. em 15/10/1996).

"(...) O regime jurídico estatutário, que disciplina o vinculo entre o servidor público, ativo e inativo, e a Administração, não tem natureza contratual, em razão do que inexiste direito a inalterabilidade do regime remuneratório, sendo passivel de modificação quando em desacordo com o teto limite constitucional. Esta colenda Corte consagrou o entendimento de que a pensão especial submete-se a incidência da legislação que determina novos critérios de fixação de seu percentual, não se encontrando imune a incidência do redutor, que deve ser calculado tomando-se como valor limite a remuneração referência do Poder a que esta vinculado o benefício. Recurso Especial conhecido e provido". (STJ, RESP 113698-SC, Sexta Turma, Rel. Min. VICENTE LEAL, DJ 01/09/1997, j. em 24/06/1997).

“(...) Militares da reserva - Pretensão de serem promovidos ao posto imediatamente superior - Tese sustentada no fato de terem ingressado no serviço público quando vigia norma que assim permitia, embora outra, existente por ocasião da passagem da inatividade, vedasse tal benefício. - Inexistência de direito adquirido. (....) Militar que entra em serviço ativo, dentro de determinada norma, não tem direito adquirido ao mesmo regime jurídico se outra passa a vigorar no decorrer de sua atividade. (....)" (STJ, RMS 4261-DF, Terceira Seção, Rel. ANSELMO SANTIAGO, DJ 08/09/1997, j. em 13/08/1997).

Essa orientação doutrinária e jurisprudencial, específica quanto ao tema da revisão do regime jurídico do servidor público, não impede a consolidação de vantagens ou a formação de direitos adquiridos frente a inovação legislativa na relação do servidor com o Estado.

Além das vantagens consumadas, isto é, aquelas que produziram no patrimônio individual todos os efeitos de que eram susceptíveis no tempo (ex.: férias gozadas), 
dos "facta praeterita", como as gratificaçōes devidas "pro labore facto", a exemplo da gratificação por substituição em cargo em comissão, anteriormente vencida mas eventualmente ainda não paga, é reconhecida a possibilidade de constituição de direitos adquiridos face à lei quando na situação jurídica individual o fato aquisitivo já tenha decorrido por inteiro sem que tenham se exaurido os seus efeitos, a exemplo do direito à qualificação de certo tempo como tempo de serviço público (STF, RE 82.881, Rel. Min. ELOY DA ROCHA, j. em 5/05/1976) e do direito ao cálculo dos proventos em conformidade com a lei vigente ao tempo em que o servidor preencheu os requisitos para a aposentadoria (STF, RE 92.638, Rel. Min. MOREIRA ALVES, RDA 145/56, j. em 6 de julho de 1980).

Não se admite, porém, direito adquirido à mera sobrevivência no tempo do regime jurídico regulador da função pública, em benefício de indivíduos determinados, pois foi vencida no plano das idéias e na história a concepção patrimonial da função pública (quando os cargos públicos eram bens negociados, comprados ou doados, e integravam o patrimônio pessoal do seu titular). Atualmente, os cargos adotam o regime legal da função pública, estando à disposição do legislador, nos limites da Constituição, repelindo-se a idéia de que o regime jurídico regulador do exercício da função, em si mesmo considerado, possa ser incorporado ao patrimônio jurídico do servidores ou da Administração.

\section{Sentido lógico e jurídico das emendas sobre direito adquirido na Reforma} Administrativa

No curso de tramitação da reforma administrativa diversas emendas foram apresentadas visando declarar, mediante enunciado expresso, a idéia da validade de direitos adquiridos face às novas alterações constitucionais.

Nenhuma das propostas foi admitida. Na verdade importavam uma contradição lógica e uma contradição jurídica.

Contradição lógica, em primeiro lugar, pois as emendas enunciavam expressamente, geralmente para uma ou duas matérias, o que se admitia como regra geral. De um lado, se as emendas eram consideradas necessárias para garantia do direito adquirido, obviamente nenhuma garantia prévia era considerada suficiente, bastante por si para a tutela destes direitos, com o que indiretamente se negava a eficácia do art. 5e, inciso XXXVI, da Constituiçāo Federal face ao poder de reforma constitucional. De outro, ao enunciarem a garantia para uma ou duas matérias, "a contrario sensu", as emendas terminavam por excluir da garantia que enunciavam diversas outras matérias também objeto de alteração específica. Nenhum desses efeitos parece congruente com as intenções dos autores das emendas ou com a justificativa que apresentavam segundo a qual "existe direito adquirido contra a reforma da Constituição".

Contradição jurídica, porque as emendas enunciavam a inaplicabilidade a todos os atuais servidores das alteraçōes operadas no regime jurídico de institutos jurídicos inteiros, como a estabilidade, quando se sabe que direito adquirido atina com situações jurídicas individuais e vantagens incorporadas no patrimônio individual. Parece 
evidente que a persistência no tempo do sistema de desligamento existente no regime jurídico anterior à reforma não conforma autêntica vantagem individual incorporável ao patrimônio jurídico de servidores públicos. É estranho ao conceito jurídico de direito adquirido a idéia de imunidade a alterações normativas abstratas, pois essa garantia não impede a modificação abstrata de institutos jurídicos, não visa bloquear a reforma legislativa. De frisar, por fim, que o regime da estabilidade, antes como depois da reforma, não constitui disciplina imutável ou absoluta, mas deixa margem à inovação do próprio legislador infraconstitucional em matéria de definição de novas faltas graves como hipóteses de perda de cargo.

As emendas dos parlamentares sobre o tema dos direitos adquiridos, no entanto, inegavelmente tiveram o mérito de abrir na sociedade o debate sobre os limites ou o alcance da garantia dos direitos adquiridos. De certo modo, alargaram o próprio debate parlamentar, tornando mais conhecido um problema técnico árduo, considerado por todos um dos problemas mais complexos da ciência do direito. A questão dos direitos adquiridos, no entanto, sempre aberta a novas abordagens e concretizações, parece encontrar solução adequada apenas quando é considerada caso a caso pelo magistrado, a quem cabe em última instância precisar os limites de aplicação de todo direito novo. 